\title{
Correction to "Bacterial Diversity Controls Transformation of Wastewater-Derived Organic Contaminants in River-Simulating Flumes"
}

Malte Posselt, Jonas Mechelke, Cyrus Rutere, Claudia Coll, Anna Jaeger, Muhammad Raza, Karin Meinikmann, Stefan Krause, Anna Sobek, Jörg Lewandowski, Marcus A. Horn,* Juliane Hollender, * and Jonathan P. Benskin*

Environ. Sci. Technol. 2020, 54 (9), 5467-5479. DOI: 10.1021/acs.est.9b06928

Cite This: Environ. Sci. Technol. 2020, 54, 9142-9142

Read Online

ACCESS | Lلll Metrics \& More | 回 Article Recommendations | st Supporting Information

The Supporting Information (section SI.N) contained concentration time trends that were incorrectly plotted. The corrected section is provided published with this Correction. The results and conclusions remain unchanged.

\section{ASSOCIATED CONTENT}

\section{(s) Supporting Information}

The Supporting Information is available free of charge at https://pubs.acs.org/doi/10.1021/acs.est.0c03798.

Concentration time trend plots (PDF) 